\title{
A HORGÁSZTURIZMUS POZÍCIÓJÁNAK ERŐSÍTÉSE MAGYARORSZÁG TURIZMUSÁBAN
}

\author{
Raffay Zoltán \\ Pécsi Tudományegyetem Közgazdaságtudomány Kar, Marketing és Turizmus Intézet; \\ raffayz@ktk.pte.hu
}

DOI: 10.15170/TVT.2022.07.01.07.

\begin{abstract}
Absztrakt
A turizmuson belül relatív részarányát stabilan növelő alternatív turisztikai tevékenységek közt egyre népszerübb az ökoturizmus, amely számos előnnyel jár a desztinációk számára, például azzal, hogy olyan erőforrásokat hasznosít, amelyek más módon közvetlen gazdasági hasznot nem hoznak a helyi közösségnek, ráadásul mindezt fenntartható módon, az erőforrások károsodásának vagy megszünésének, elfogyásának veszélye nélkül. Magyarország egy, az ökoturizmus és az aktív turizmus határterületén található turisztikai tevékenység, a horgászturizmus területén kiváló, eddig jórészt kihasználatlan lehetőségekkel rendelkezik, és számos ígéretes kezdeményezés szolgálhat követendö példaként. Az ország legnagyobb civil szervezete, a mára mintegy 800 ezres taglétszámot számláló Magyar Országos Horgász Szövetség (MOHOSZ) számos, a horgászturizmust (is) segítő kezdeményezést vagy intézkedést hozott az elmúlt években: eredményes lobbizás a természetes vízi kereskedelmi célú halászat megszüntetéséért, a tagegyesületeket információkkal és tanácsadással segítő Országos Horgászszervezeti Szolgáltató Központja (OHSZK) müködtetése, intervenciós halvásárlással a horgászvizek bizonyos körének halasításához való hozzájárulás stb. A tanulmány a horgászturizmus potenciálját elemzi hazánkban, bevezetőjében kitérve az ökoturizmus és az aktív turizmus tágabb összefüggéseire.
\end{abstract}

Kulcsszavak: horgászturizmus, ökoturizmus, jó gyakorlatok, fizikai tevékenységeken alapuló turizmus 


\title{
STRENGTHENING THE POSITION OF ANGLING TOURISM IN THE TOURISM SECTOR OF HUNGARY
}

\begin{abstract}
Among the alternative touristic activities with steadily growing popularity, ecotourism is of growing significance. Ecotourism is beneficial from several aspects for the destinations, by utilising resources that may not offer direct economic advantage for the local communities otherwise, and all this in a sustainable manner, without the danger of damaging or annihilating (consuming) the natural resources. Hungary has excellent (and so far mostly underutilised) endowments in a specific touristic activity on the border of ecotourism and activity-based tourism: this is angling tourism. There are several promising initiatives that can serve as best practices for those interested in becoming angling tourism service providers. The largest nongovernmental organisation of Hungary, the Hungarian National Angling Association, with its approximately 800,000 members, has launched several initiatives assisting angling tourism in the recent years (successful lobbying activity for the prohibition of large-scale commercial fishing on natural waters; servicing and advising for member associations; contribution to the purchase and stocking of indigenous fish species etc.). The paper is a brief analysis of the potential of angling tourism in Hungary, also mentioning the broader correlations of ecotourism and activity-based tourism in the introductory chapter.
\end{abstract}

Keywords: angling tourism, ecotourism, tourism based on physical activities, good practices 


\section{Bevezetés}

Immáron közhely, hogy a turista egyre inkább élményt vár el a pénzéért, egyre kevésbé elég, ha hagyományos attrakciókkal várja egy desztináció. Látszik ez az elmúlt évek, évtizedek trendjeiből: ilyenek a hagyományos tengerparti tömegturizmus súlyának csökkenése a turizmus összességén belül, és az alternatív vagy akár extrém tevékenységek súlynövekedése (IPK INTERNATIONAL 2016, RAFFAY 2014). Nem várhatjuk természetesen, hogy az arányok a közeljövőben megfordulnak és a mai tömegturisztikai formák kevesebb utazót csábítanak majd, mint az alternatív turisztikai tevékenységek, de aki utazni szeretne, azok számára egyre több lehetőség áll rendelkezésre úgy az elérhető desztinációk, mint az igénybe vehető turisztikai szolgáltatások vagy üzhető tevékenységek terén, és így a turizmus kevésbé tömegszerü formáinak térhódítása valószínüleg a jövőben is folytatódik (THENG et al. 2015). A Covid 19 járvány hatására is felértékelődtek a szabadban végezhető tevékenységek, és a természethez közeli területek (CSÓKA et al. 2021, KOVÁCS et al. 2021).

Ha a turista egyre több élményt vár el a pénzéért, a desztinációknak és az ott müködö szolgáltatóknak, de a turizmusban tevékenykedő egyéb érintetteknek is egyre inkább komplex kínálatot kell biztosítaniuk. Ennek egyik módja, ha minél változatosabb programokat kínálnak a vendégnek. Ahogy a tudományban is egyre gyakoribb az interdiszciplináris megközelítés, a tudományterületek együttmüködése, úgy a turizmusban is egyre inkább elmosódik a határ az egyes tevékenységek és termékek között (MICHALKÓ 2011).

Számos esetben nehéz meghúzni a határvonalat az egyes turisztikai termékek közt, illetve nehéz eldönteni, hogy egy bizonyos turisztikai tevékenység melyik kategóriába tartozik. Hogy csak a címben szereplö turisztikai tevékenységeknél maradjunk, egy védett természeti területre tett kenutúra vagy horgásztúra az aktív turizmus kategóriájába ugyanúgy besorolható, mint az ökoturizmuséba, egy nem kiépített barlangban tett túra komoly fizikai erőfeszítéssel is járhat.

A turisztikai tevékenységek közti szinergiák vizsgálata nem új a turizmus kutatásában (MICHALKÓ 2011, HUSZTI et al. 2014), ezen szinergiák kihasználásával a vendégek tartózkodási ideje, költési hajlandósága, akár a desztináció iránti hüsége is növelhető - és persze általában az elégedettségük, amely a desztinációk vendégkörének stabilizálódásához, vagy a szájreklám (WoM), az internetes blogok, fórumok kínálta lehetőségek révén a pozitív visszajelzések segítségével azok erösödéséhez vezethet.

Vannak olyan turisztikai tevékenységek, amelyek között a szinergia több mint nyilvánvaló (MICHALKÓ 2011). Az összes turisztikai tevékenység kapcsolódási pontjainak elemzése messze meghaladná e tanulmány kereteit, e helyütt csupán az ökoturizmus, az aktív turizmus és a horgászturizmus szinergikus hatásainak rövid bemutatására vállalkozik a szerző az adott turisztikai tevékenységek egymáshoz való kapcsolódási pontjainak részletesebb elemzése előtt. Elötte azonban tekintsük át röviden az egyre növekvő népszerüségük mögött álló okokat.

\section{Az ökoturizmus, az aktív turizmus és a horgászturizmus népszerüségének növekedése}

Az ökoturizmus és az aktív turizmus definíciójától e helyütt eltekintünk, feltételezve, hogy az olvasó ismeri azokat - ha mégsem, a szakirodalomban bőséges információt talál róla (az ökoturizmus esetében többek között Országos Ökoturizmus Fejlesztési Stratégia, HORVÁTH - RIMÓCZI 2011, KELEMEN 2006, míg az aktív turizmusnál föleg CSAPÓ et al. 2011 lehet ilyen forrás), a horgászturizmus definíciója a tevékenységről szóló bekezdésben szerepel. A következő bekezdésekben a három turisztikai tevékenység növekvő népszerüsége mögötti okokat taglalja a tanulmány. 


\section{Ökoturizmus}

Korunk társadalmai sokkal fogékonyabbaknak tünnek az ökológiai problémák iránt, mint a megelöző generációk. Ami sokáig tudományos-fantasztikus, vagy katasztrófafilmekbe illő vízió volt - a Föld éghajlatának megváltozása, a felmelegedés miatt tengerszint-emelkedés, fajok eltűnése -, az mára sajnos a szomorú valóság és mindennapi életünket meghatározó tény lett. A kérdés már nem az, hogy melegszik-e a Föld átlaghőmérséklete, hogy tünnek-e el élőhelyek a megemelkedett tengerszint miatt, hanem az, hogy sikerül-e ezt valamilyen szinten irányítható keretek közt tartani vagy az emberiség egészének jövőjét fenyegető katasztrófával nézünk szembe. A környezeti kérdések már életünk meghatározó részévé váltak, és ez is közrejátszik abban, hogy a turizmus iparágon belül is egyre erősödik a fenntarthatóság eszméjét szem előtt tartva végzett turisztikai tevékenység, az ökoturizmus (FENNELL 1999).

\section{Aktív turizmus}

Ugyan globális problémának nem nevezhető, de a fejlett ipari társadalmak szinte mindegyikére jellemző a lakosság egészségi állapotának negatív irányú változása - elsősorban a komoly egészségügyi problémákat (és kiadásokat) generáló túlsúly, elhízás. A civilizációs betegségnek is tekinthető túlsúly egyik ellenszere az intenzívebb mozgás lehet - ez a turizmus aktív formáinak a térnyerését segíti elő. Nemcsak az egészségtudatosság, hanem más trendek (pl. környezettudatos, a passzív pihenés helyett egyre inkább keresik az autentikus élmények keresése többek között olyan természeti értékekkel rendelkezö területeken, amelyek alkalmasak szabadtéri aktivitásokra) miatt is nő az aktív turizmus népszerüsége (amelyre a COVID-19 járvány akár jótékony hatással is lehet, lévén a szabadban a vírus is nehezebben terjed és sokkal könnyebb betartani a biztonságos távolságot a többi turistától). Az aktív turizmus kategóriájába a Magyar Turisztikai Ügynökség szerint a természetjárás, a kerékpáros, vízi, vitorlás, lovas, kaland- és extrém turizmus, a golf-, horgász-, vadász-, futó-, sí- és ökoturizmus tartozik (mtu.gov.hu).

Az aktív turizmus fejlesztése az utóbbi években egyre jobb megítélésnek örvend a turizmusfejlesztésen belül hazánkban is. Az aktív turisták megjelenése és a turisztikai termék fejlesztése nagyobb vonzerőt jelentene az ország számára, ezzel az elmaradottabb területeket és a vidékfejlesztést támogatnánk (CSAPÓ et al. 2011).

\section{Horgászturizmus}

A hazai turisztikai szakirodalomban kevesek által kutatott terület a horgászturizmus, amelynek a csekély mennyiségü szakirodalomban is többféle definíciójával találkozhatunk. A legjobb talán SZÉKELY (2016) meghatározása: a horgászturizmus olyan, az állandó tartózkodási helyen (helyeken) kívül, vízen vagy vízparton történő aktív szabadidős tevékenység, mely egyetlen célja a halfogás és általában kapcsolódik hozzá helyszíni szolgáltatások igénybevétele. A horgászturizmus hazai népszerüségének növekedéséhez számos tényező hozzájárul:

- a horgászok létszámának dinamikus növekedése (1. ábra, 1. táblázat) - a létszám a 2022. évre megközelítette a 800 ezret (az állami horgászengedélyt nem, csak turista horgászjegyet váltó horgászokat is beleszámolva ${ }^{33}$ ), vagyis hazánk lakosságának mintegy 8\%.-a horgászik, ez európai összehasonlításban is magasnak mondható;

\footnotetext{
${ }^{33}$ Horgászengedély ma Magyarországon csak horgászvizsga letételét követően váltható ki, azonban néhány éve bevezetésre került egy olyan megoldás, amellyel a rendszeresen nem, csak alkalmilag horgászó turisták bizonyos alapvető horgászati ismeretek elsajátításával, egy online teszt kitöltését követően egy maximum 90 napra szóló jegyet válthatnak kedvezményes áron. Nem szükséges hivatalos vizsgát tenniük, egyesületbe belépniük, így egy olyan célcsoport is megnyerhető a horgásztatnak, akiket egy bonyolultabb procedúra valószínüleg visszatartana e szabadidős tevékenység folytatásától.
} 
- a természetes vízi nagyüzemi halászat megszüntetésével nagy természetes vizeink, például a Duna hallállománya érezhetően gazdagabb lett, több fogást kínál és nagyobb élményt nyújt a természetes vizeken történő horgászat;

- sikeres hazai kezdeményezések: horgászversenyek (pl. az International Balaton Carp Cup, IBCC) és a horgászturizmusra kiemelt figyelmet fordító vízterületek (pl. Háromfa, Merenye, Maconka stb.);

- a 2020-as évben a Covid pandémia miatti korlátozások kevésbé érintették a belföldi turizmust, a horgászat ráadásul az egyik legbiztonságosabb szabadidő-eltöltési forma (szabadban zajlik és nagyon könnyü betartani a horgásztársak közötti fizikai távolságot).

1. ábra: A horgászok számának alakulása Magyarországon 1945 és 2012 között

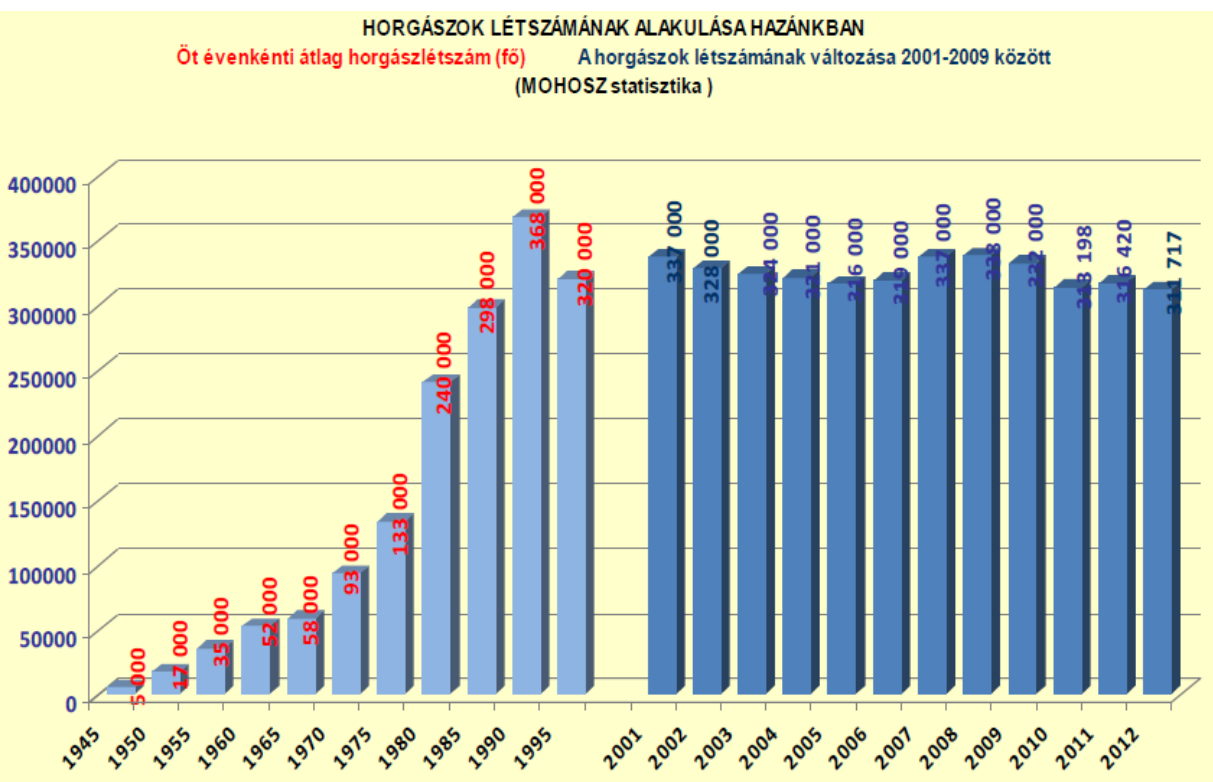

Forrás: FÜRÉSZ-ZELLEI é.n.

1. táblázat: A kiváltott (felnőtt és gyermek) állami horgászjegyek száma Magyarországon, 2013-2017

\begin{tabular}{|c|c|c|c|c|c|c|c|c|c|}
\hline \multicolumn{5}{|c|}{ Kiváltott felnőtt állami horgászjegyek száma } & \multicolumn{5}{|c|}{$\begin{array}{l}\text { Kiváltott gyermek állami horgászjegyek } \\
\text { száma }\end{array}$} \\
\hline 2013 & 2014 & 2015 & 2016 & 2017 & 2013 & 2014 & 2015 & 2016 & 2017 \\
\hline 357483 & 367689 & 375180 & 407423 & 442493 & 48211 & 50093 & 48344 & 51411 & 59817 \\
\hline
\end{tabular}

Forrás: https://portal.nebih.gov.hu

Ugyanez a portál 2021 októberében már 800000 főt meghaladó létszámról írt. Az alábbi ábrán jól látszik, hogy a mai horgászlétszám alig több mint harmadával Magyarország az európai középmezőnybe tartozott a horgászoknak a teljes lakosságszámon belüli arányát tekintve, a mai létszámmal már nem 3,1\%, hanem mintegy $8 \%$ az ezen sportot szervezett keretek között üzők száma hazánkban, amivel - a külön kategóriát képező három skandináv országot nem számítva - az európai élmezőnyben foglalunk helyet. 
2. ábra: A horgászok száma népességarányosan az egyes európai országokban

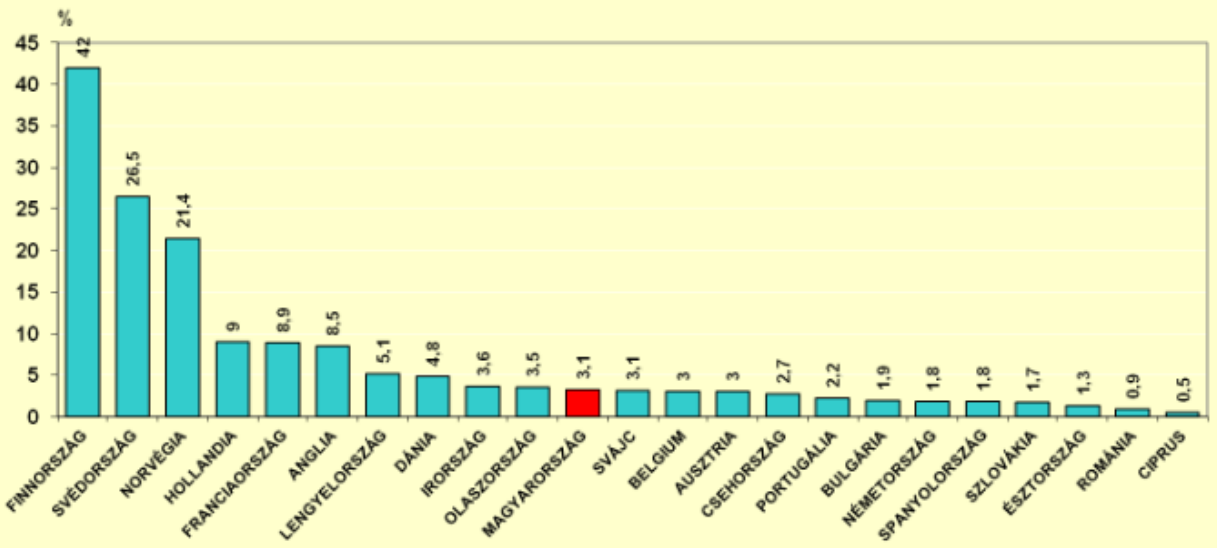

Forrás: FÜRÉSZ-ZELLEI é.n.

\section{A horgászturizmus kapcsolódásai más turisztikai termékekhez}

A horgászturizmus elsősorban az aktív és ökoturizmussal, illetve a falusi- és agroturizmussal hozható összefüggésbe (3. ábra).

3. ábra: A horgászturizmus szinergikus kapcsolatai más turisztikai termékekkel

\begin{tabular}{|c|c|c|c|c|c|c|c|c|c|c|c|}
\hline & 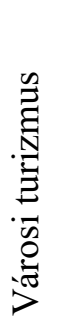 & 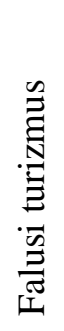 & 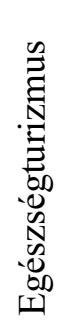 & 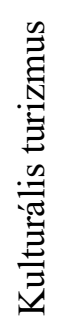 & 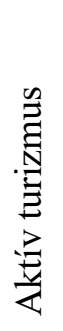 & 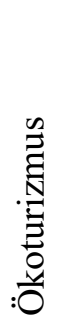 & 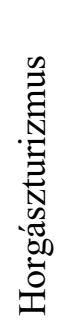 & 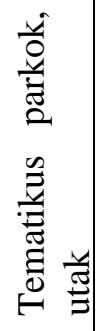 & 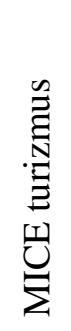 & 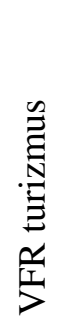 & 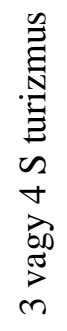 \\
\hline Városi turizmus & & $\mathrm{X}$ & & & & & & & & & \\
\hline \multicolumn{12}{|l|}{ Falusi turizmus } \\
\hline \multicolumn{12}{|l|}{ Egészségturizmus } \\
\hline \multicolumn{12}{|l|}{ Kulturális turizmus } \\
\hline \multicolumn{12}{|l|}{ Aktív turizmus } \\
\hline \multicolumn{12}{|l|}{ Ökoturizmus } \\
\hline \multicolumn{12}{|l|}{ Horgászturizmus } \\
\hline \multicolumn{12}{|c|}{ Tematikus parkok, utak } \\
\hline \multicolumn{12}{|l|}{ MICE turizmus } \\
\hline \multicolumn{12}{|l|}{ VFR turizmus } \\
\hline
\end{tabular}

Jelmagyarázat: X: egymást kizáró tényezők; $\square$ : erős kapcsolat; $\square$ : közepesen erős kapcsolat; $\square$ : gyenge kapcsolat ${ }^{34}$

Forrás: MICHALKÓ et al. (2011) alapján a szerzö

\footnotetext{
${ }^{34}$ „Nincs kapcsolat” kategóriát szándékosan nem szerepeltettünk; bármely turisztikai motivációval érkező vendég érdeklődhet olyan turisztikai termékek iránt is, amelyek közt a kapcsolat nem evidens. Ma már létezik „urban fishing", vagyis városi horgászat nevü kategória is (Amszterdam Párizs, London, Budapest, hogy csak néhány példát említsünk), de jellemzően nem generál horgászturizmust, sokkal inkább a helyi horgászok kedvteléséről
} 


\section{A horgászturizmus gazdasági jelentősége Magyarországon}

A „horgász-halas” szektor a magyarországi halgazdálkodást, haltermelést, az ezzel kapcsolatos keresleti és kínálati igényeket, szakmai és társadalmi, rekreációs szolgáltatásokat nyújtó, igénybe vevő és támogató szervezetek és személyek, azok szellemi és gazdasági teljesítményének összessége. A szektor ágazatokra, azokon belül specializációkra (elkülöníthető részekre) és ágazatközi specifikumokra (sajátosságokra) osztható (4. ábra). Számítási metodikától függően 40-100 milliárd forint közvetlen gazdasági teljesítményt eredményez évente, 4000 - 7000 munkavállaló, alkalmazott dolgozik az ágazatban és 700 ezer - 1,5 millió fő érintett szolgáltatás és/vagy termékvásárlóként (DÉRER 2021).

A szektor társadalmi jelentősége messze túlmutat a GDP-hez való hozzájárulásán, sőt, nem is ez az elsődleges feladata, hanem a hanem a széles személyi kört érintő rekreációs szolgáltatások és az ökoszisztéma-szolgáltatások biztosítás, valamint a vízvisszatartás, kapcsoltan a mikroklíma támogatása, figyelemmel az évszázados halászati hagyományokra és a nemzeti horgászsport jelen sikereire is (DÉRER 2021). Bár ae a hír nem éri el az állami média ingerküszöbét és valószínüleg az átlagembert sem érdekli a horgászat annyira, mint a látványsportok, mindenképen érdemes megjegyezni és akár marketingértékkel is bírhat, hogy jelen pillanatban (a 2022. év elején) a magyar horgászválogatottat tartják a szakmai szervezetek a világ legjobbjának (mohosz.hu), olyan, a horgászsportban hagyományosan élenjáró nemzeteket megelőzve, mint Anglia, Franciaország, Olaszország vagy Belgium.

4. ábra: A magyar horgász és halas szektor összetétele

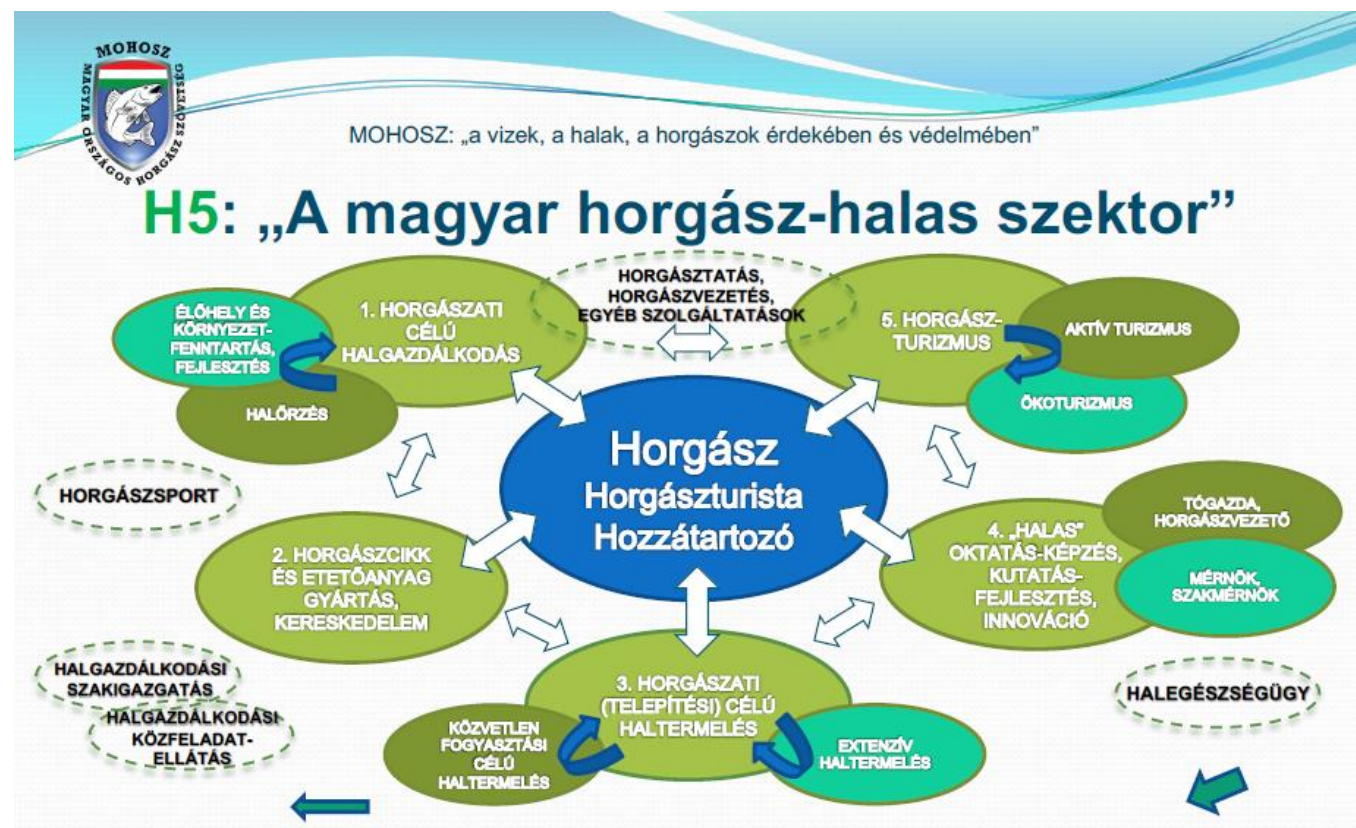

Horgászati cólú NEMZETI HALGAZDALKODASI- Es HORGASZATI STRATÉGIA (NHHS)

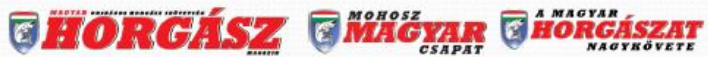

2021.10.03

„A jövő kihívásai a horgászat és haltermelés területén” szakkonferencia, Budapest

Forrás: DÉRER 2021

van szó - ami persze nem zárja ki elsődleges vagy sokadlagos turisztikai motivációként a horgászatot a (nagy)városi desztinációkban. Hasonlóképpen a horgászturizmus iránt érdeklődő vendégek megtekinthetik a környék kulturális értékeit is, érdeklödhetnek a gasztronómia iránt, a VFR turizmus keretében egy adott desztinációba érkezők a környék horgászati lehetőségeit is kipróbálhatják stb. 


\section{A horgászszervezetek horgászturisztikai tevékenysége Magyarországon}

A horgászok ma (Magyarország legnagyobb létszámú hálózatos civil szervezeti rendszerét alkotva) mintegy 1200 horgászegyesület keretei között hódolhatnak szenvedélyüknek (www.mohosz.hu). Az egyesületek nagy része túlságosan kicsi ahhoz, hogy a horgászturizmus szervezésében tevékeny részt vállalhasson és többnyire ehhez a humán és egyéb erőforrások is hiányoznak, a horgászat „csúcsszerve”, a Magyar Országos Horgász Szövetség azonban tudatosan és tervszerüen fejleszti a horgászturizmust hazánkban.

\section{A Magyar Országos Horgász Szövetség szerepe a horgászturizmus fejlesztésében}

Hazánk legnagyobb civil szervezete az 1947-ben alapított Magyar Országos Horgász Szövetség (MOHOSZ). Alapszabályában az alábbi célkitüzéseket határozza meg (a dőlt betűs kiemelés a szerzőtől származik és az ökoturisztikai, illetve horgászturisztikai relevanciával bíró részekre terjed csak ki): „A Szövetség elsődleges célja a halgazdálkodás, benne a horgászat és a horgásztatás általános feltételrendszere biztosításának elősegítése, érdekeinek előmozdítása és megvédése".

„A Szövetség céljai és egyben fontosabb tevékenységei a következők:

- a horgászat és a horgászsport társadalmi népszerüsítése, a horgászlétszám emelése, a sporthorgászat elveinek, a halfogás sportszerüségének, a kulturált vízparti magatartásformáknak széles körü elterjesztése, a kapcsolódó etikai normák kialakítása, megismertetése, fejlesztése;

- a horgászat és a halgazdálkodás hagyományainak megőrzése és ápolása;

- a horgászat gazdaságának fejlesztése, a horgászturizmus hatásainak erősitése, horgászati célú halgazdálkodás gyakorlati folytatása az értékmegőrzés fenntartásával, kapcsolódó, fenntartható horgászturisztikai szolgáltatások kialakitásával, végzésével, fejlesztésével;

- elsődlegesen horgászati célú, komplex és ökológiai szemléletü halgazdálkodás, benne a horgásztatás, valamint a szabadidós sporthorgászat és a horgász versenysport szervezése és fejlesztése, egységes belső szabályozása;

- a természet és a vízi környezet védelme, a vízpartok rendben tartása, környezetvédelmi tevékenység végzése, a horgászat, a horgászsport szervezése és fejlesztése oly módon, hogy annak gyakorlása során a természet-és környezetvédelmi érdekek lehetőleg ne sérüljenek;

- a természetes vízi halállományok mennyiségi és minőségi növelése, a telepítésekhez és visszatelepítésekhez őshonos halfajok szaporítása, horgászszervezeti halbeszerzési és telepítési koordinációs feladatok ellátása;

- a vizek renaturálása, revitalizálása, ... a Szövetség és tagszervezetei tulajdonában, bérletében, illetve hasznosításában lévő vizek rehabilitációja, a rehabilitációs tevékenység előkészítése és támogatása ...;

- kedvező horgászturisztikai és egyéb szolgáltatások lehetöségének biztositása a Szövetség keretében szervezett horgászok számára" (www.mohosz.hu).

A MOHOSZ az elmúlt években egyre aktívabban vesz részt a horgász közélet, valamint a horgászturizmus fejlesztésében, az alábbi tevékenységek révén:

- A keretfeltételek megteremtése: a természetes vizek nagyüzemi halászatának megszüntetésével azok vonzereje jelentős mértékben nőtt (hozzáférés javulása, és elsősorban érezhetően javuló, erősödő halállomány). A döntés nem a MOHOSZ részéről született, de a szervezet aktív lobbitevékenysége fontos volt hozzá; 
- Konkrét támogatások: pályázati rendszerben kérhetnek támogatást az őshonos halállomány erősítésére és a horgászturizmust is szolgáló infrastruktúra kiépítésére, eszközök vásárlására a tag egyesületek számára;

- Tanácsadási szolgáltatások: az Országos Horgászszervezeti Szolgáltató Központja (OHSZK) müködtetése tartozik ebbe a körbe.

A MOHOSZ horgászturizmust támogató tevékenysége mellett érdemes szót ejteni hazánk egyik legnagyobb és (jogelődjét is tekintve) legrégibb, állami tulajdonú halgazdálkodási vállalatáról, a Balatoni Halgazdálkodási Nonprofit Zrt. tevékenységéről a horgászturizmus területén (https://balatonihal.hu). A jelen formájában 2009. augusztus 25-e óta müködő szervezet az ország egyik legrégebbi agrárgazdasági vállalatának, a Balatoni Halászati Zrt.-nek, sőt az 1899-ben alapított Balaton Halászati Részvénytársaság a jogutódjaként jött létre, és 100 \%-ban a Magyar Állam tulajdona. A Társaság fó feladata a Balaton ökológiai szemléletü halgazdálkodásának megvalósítása amellyel többek között a természeti értékek védelmét és a minőségi turizmus feltételeit is biztosítja. A feltétetlek biztosításán túl a Társaság legfontosabb tevékenységei között ott van a „horgászturisztika fejlesztésében való aktív részvétel” is (https://balatonihal.hu). A balatoni horgászengedélyek kiadásán túlmenően a Társaság maga is aktív ökoturisztikai szereplővé vált a Süllőfészek Vendégházzal, illetve a Keszthelyen kialakított horgászturisztikai szálláskomplexummal, az Akvárium Apartmanházakkal (http://akvariumapartmanhazak.hu). Utóbbi a szálláshely biztosításán től vezetet horgásztúrákkal közel komplex szolgáltatáscsomagot nyújt.

A Balatoni Halgazdálkodási Nonprofit Zrt. (a MOHOSZ-szal együtt) a fó támogatója a mára nemzetközi hírüvé vált IBCC rendezvénynek (International Balaton Carp Cup, Nemzetközi Balatoni Pontyfogó Kupa). A tó egész területére kiterjedő nemzetközi versenyt 2015-ben rendezték meg először, 50 csapattal. A második alkalommal már 83 csapat regisztrált, mára ez a szám közel 200-ra nőtt (2022. januárjában már 172 csapat íratta fel magát a 2022. április megmérettetésre, lásd https://ibcc.hu). Mivel csapatonként három fö vehet részt a versenyben, félezernél is több vendéget jelent a Kupa csak a versenyzőket tekintve, nem beszélve a kísérőkről, a szervezőkről, a médiáról - jelentős vendégéjszaka- és vendéglátóipari forgalmat generálva a föszezonon kívül (a Kupát eddig minden évben áprilisban vagy októberben rendezik, illetve rendezték). A Kupa minden túlzás nélkül mondható nemzetközinek, hiszen idén a 38 magyar csapat mellett további húsz európai országból érkeznek versenyzők (érdekes, hogy Csehországból a hazaiaknál többen, 47 csapat nevezett, míg Szlovákia és 23, Románia pedig 16 csapattal képviselteti magát). Az igen sikeres versenysorozat feltette a Balatont Európa horgásztérképére.

A hazai horgászturizmust is nagyban segíti a Balatoni Halgazdálkodási Nonprofit Zrt. által müködtetett Balatoni Horgászturisztikai Adatbázis (http://adatbazis.balatonihal.hu), amely részletes tájékoztatást nyújt a legnagyobb tavunk partjára horgászat céllal érkező vendégek részére nem csupán a horgászturizmus infra-, de szuprastruktúráját - horgászbarát szállások, jegy- és felszerelés-vásárlási lehetőségek, csónakbérlés stb.) - tekintve is (5. ábra). Az ikonokra kattintva az adott partszakaszhoz tartozó konkrét információk jelennek meg. 
5. ábra: Balatoni Horgászturisztikai Adatbázis térképes helykereső

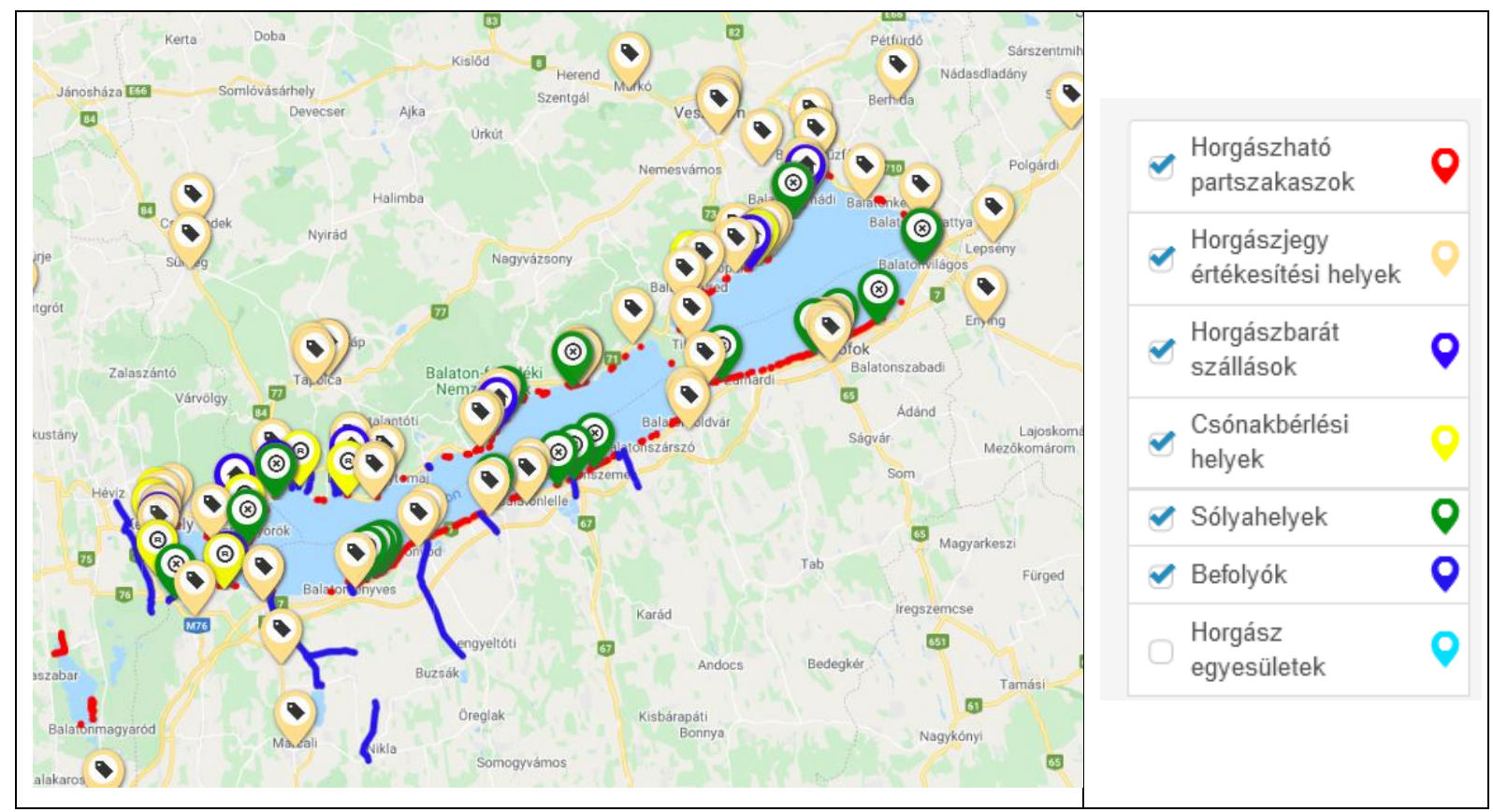

Forrás: http://adatbazis.balatonihal.hu/

Teendők a horgászturizmus további fejlesztése érdekében Magyarországon

\section{A legjobb gyakorlatok átvétele}

A horgászturizmusnak Magyarországon is vannak hagyományai és jó gyakorlatai, de más országoknak is vannak olyan hasznosítható tapasztalatai, amelyekre építeni lehet. Az alábbiakban néhány ilyen kezdeményezést és müködő gyakorlatot mutatunk be.

Svédország délkeleti részén 1999-ben a svéd gazdaszövetség kezdeményezésére mintegy három tucat szolgáltatóval indult a Det Naturliga Fisket (természetes vízi horgászat) elnevezésü projekt. A finanszírozás három oldalról érkezett: a résztvevő megyék, az Európai Unió Strukturális Alapjai és az érintett szolgáltatók adták össze az induláshoz szükséges összeget. A szervezet célja a horgászturizmus népszerüsítése, magas minőségű szolgáltatások nyújtásával. A tagságra jelentkezni kell, és csak azok a szolgáltatók kerülhetnek be a körbe, akik a négyféle kritériumnak megfelelnek (megfelelő vízterület; termékek és azokról szóló információk; marketing; szakértelem és hálózatosodás). A szolgáltatók megfelelő ökológiai felkészültségét szintén ellenőrzik (GÖSSLING - HULTMAN 2006). A tagok meglehetősen magas összegü tagdíjat fizetnek, cserébe részesülnek a szervezet által nyújtott előnyökből (marketing, presztízs, információ, vendégkör). Induláskor a projektben résztvevők alapos képzésben részesültek. A projekt alig néhány év után önfenntartóvá vált.

A Duna-Delta európai (sőt aligha túlzás állítani, hogy világ-) hírü desztináció, UNESCO világörökségi helyszín, nemzeti park, bioszféra rezervátum. Világhírü madárvilága mellett halállománya legalább akkora vonzerőt gyakorol az európai kontinens horgászaira. Számos vállalkozás állt rá a horgászturizmus szervezésére és mára már akár szakosodott horgásztúrák is kérhetök (https://www.wilddanube.ro).

Vannak kifejezetten nagy halak (Európában ez elsősorban a leső harcsát jelenti) fog(at)ására szakosodott vállalkozások is, mint például a Giant Hunters Fishing Holidays (https://www.gianthuntersfishingholidays.com).

Hazai viszonylatban is vannak jól menedzselt és sikeres horgászturisztikai kezdeményezések, az ország legkülönbözőbb tájegységeiben és a horgászat többféle válfaját tekintve. 
A Tisza-tó horgászturizmusa több évtizedes múltra tekinthet vissza. Számos olyan szolgáltatást nyújtanak a Tisza-tó környéki vállalkozások (pl. csónakbérlési lehetőség és túravezető igénylése a tó, felfedezéséhez, ismeretterjesztő tanösvény kialakítása), amelyek példaértéküek lehetnek (HALASI-KOVÁCSNÉ et al. 2014).

A Vas megyei pisztrángos patakok kialakításával hazánk kevés pisztrángos vize egy kimondottan a horgászvendégeknek szánt szakasszal bővült a Gyöngyös-patakon: Lukácsházánál és Vasszécsénynél. A két szakaszon kizárólag a legsportszerübbnek tartott mülegyezéssel és pergetéssel, a halak maximális kímélése (szakáll nélküli horog használata) mellett szabad csak horgászni.

A Somogy megyei Háromfán, illetve Baranya megye somogyi határán található Merenyén a bojlizás a legelterjedtebb és tavak hírnevét megalapozó, majd a kiterjedt horgászturizmust éltető módszer. A tavak népszerüségét mi sem mutatja jobban, mint hogy elöre lefoglalt helyeken lehetséges csak a horgászat: a 2022 év elején áprilistól októberig a helyek nagy része már le volt foglalva a Merenyei-tavon és nem egy helyen a hét hónapos időszakban már alig háromnégy nap maradt szabadon az erre a célra létrehozott Facebook oldal tanúsága szerint.

A Nógrád megyei Bátonyterenye melletti Maconkai-víztározó vízrendszere vonzereje elsősorban komplexitásában rejlik: 45 halfaj fogható itt, köztük különlegességek is;van kifejezetten kapitális halakkal telepített tó, vannak versenypályák, és a horgászat mellett a turisztikai szuprastruktúra is megfelelően kiépített (RAFFAY 2009).

\section{Marketing}

A horgászturizmus fejlesztése elképzelhetetlen a szolgáltatás-szervezési háttér, illetve a marketing fejlesztése nélkül. A magyarországi horgászturizmus eddigi sikerei aligha a céltudatos marketingtevékenységnek, sokkal inkább a szájhagyománynak, a visszatérő és a vizek jó hírét keltő horgászok propagandamunkájának köszönhetőek (RAFFAY 2020). A Magyar Országos Horgász Szövetség az elmúlt években kezdett intenzívebb tevékenységbe e téren. Egyes desztinációk (például Maconka) elindultak imázsfilmek készítésével és intenzívebb reklámtevékenységgel a horgászturizmus erősítésének irányában, az angol, ír stb. példákhoz képest azonban még rengeteg a tennivaló.

Marketing szempontból talán a legfontosabb egy jól müködő honlap, amely az adott vízterületre vonatkozó horgászati lehetőségeken kívül tartalmazza a horgász számára fontos szolgáltatókat (szállás, jegybizományos, horgászbolt, stb.), naprakész információkat közöl a haljárásról, vagyis félig-meddig horgászati hírportálként is müködik (számos vízterületnek van aktívan müködő Facebook-csoportja, hasonló funkcióval). Nagyon fontos szolgáltatási forma lenne, és az igények között előkelő helyen szerepel a horgászbarát szálláshely, amelynek tartalmát, illetve a minősítés szempontjait és a minősítési rendszerét érdemes lenne kidolgozni (az ezzel kapcsolatos feladatokat a Magyar Országos Horgász Szövetség is elláthatná).

Szintén meghatározó szolgáltatás lehet a horgászvezető, akinek igénybevételével a helyismeret megszerzésére fordítandó idő jelentősen lecsökken. A horgászvezetőket elsősorban a helyi horgászok közül kell kiválasztani, és egységes képzést lenne szükséges számukra bevezetni (erre legalkalmasabb szervezet szintén a Magyar Országos Horgász Szövetség lehetne, de a Balatoni Halgazdálkodási Nonprofit Zrt. is képes lenne erre).

A szolgáltatásokkal kapcsolatosan mindenképpen érdemes méltányolni azon önkormányzatok törekvéseit, akik az átlagosnál többet tesznek a horgászturizmusért, ahol komplex horgászturisztikai szolgáltatásrendszert állítanak fel. Öket és a munkájukat érdemes lenne elismerni a „Horgászbarát település” cím odaítélésével, és külön keretből bemutatni őket például egy-egy rövidfilmben, vagy akár további fejlesztésre vagy marketingre forrást biztosítani számukra (LUKÁCS 2014). 


\section{Összefoglalás}

Az egyre tájékozottabb, egyre magasabb elvárásokkal jelentkező turisták igényeinek kielégítésére kézenfekvő megoldás, ha komplex szolgáltatásokkal, az egyes turisztikai tevékenységek közti szinergiahatásokat kihasználva várja egy desztináció a látogatókat. Vannak olyan turisztikai tevékenységek, amelyek között viszonylag erösek a szinergikus hatások - ilyen többek között az aktív, az öko- és a horgászturizmus, mivel számos közös vonásuk van: az öko- és horgászturizmus kizárólagosan, az aktív turizmus pedig jelentős részben természeti erőforrásokra épül; egyik sem tömegturizmus; és mindegyikhez egyfajta elhivatottság, alázat szükséges. Vannak olyan turisztikai tevékenységek, ahol nem is állapítható meg egyértelmủen, hogy melyik kategóriába tartoznak: a tereplovaglás, a kenuzás, a terepkerékpározás, egy barlangi túra éppúgy lehet ökoturisztikai, mint sport- vagy aktív turisztikai tevékenység. A hazai ökoturizmus egyik dinamikusan fejlödő szegmense a horgászturizmus, amelynek növekvő sikereiben szerepelt játszik az ország legnagyobb civil szervezetének, a Magyar Országos Horgász Szövetségnek a célirányos tevékenysége is. Ahhoz azonban, hogy az ágazat a mainál jelentősebb gazdasági, munkahelyteremtő és szezonhosszabbító hatással bírjon és nemzetközi szinten is sikeres legyen, sok még a tennivaló.

\section{Irodalomjegyzék}

CSAPÓ, J. - SAVELLA, O. - REMENYIK, B. (2011): Aktív turizmus. In: Michalkó Gábor (szerk.): Turisztikai terméktervezés és fejlesztés. Pécs: PTE TTK Földrajzi Intézet; PTE IGYK Gazdaságtudományi és Turisztikai Intézet, pp. 1-30.

CSÓKA, L. - PAIC, R. - PRISZTÓKA, GY. - VARGÁNÉ SZ. K. - VARGA, T. - MARTON, G. (2021): A hazai utazási szokások változásai a koronavírus-járvány hatására. TURISZTIKAI ÉS VIDÉKFEJLESZTÉSI TANULMÁNYOK 6(4) pp. 16-27.

FENNEL, D. A. (1999): Ecotourism. And introduction. Routledge, London - New York

GÖSSLING, S. - HULTMAN, J. (2006): Ecotourism in Scandinavia: Lessons in Theory and Practice. $\mathrm{CABI}$

HORVÁTH, P. - RIMÓCZI, CS. (2011): Ökoturizmus. In: Michalkó, G. (szerk): Turisztikai terméktervezés és fejlesztés. http://www.eturizmus.pte.hu/szakmai-anyagok/Turisztikai terméktervezés és fejlesztés/book.html

HUSZTI, ZS. - RAFFAY, Z. - FRESLI, M. (2014): Development of rural tourism as a tool for the preservation of culture. Vestnik Karagandinskogo Gosudarstvennogo Universiteta Seriya Ekonomika 75(3) pp. 18-21.

IPK INTERNATIONAL: ITB World Travel Trends Report 2013/2014. Letöltés helye és ideje: http://www.itb-berlin.de/media/itb/itb_dl_all/itb_presse_all/WTTR_Report_2014_Web.pdf, letöltés dátuma: 2016. 07. 28.

KOVÁCS, L. - KELLER, K. - TÓTH-KASZÁS, N. - SZŐKE, V. (2021): A Covid19-járvány hatása egyes turisztikai szolgáltatók müködésére: azonnali válaszok és megoldások. TURISZTIKAI ÉS VIDÉKFEJLESZTÉSI TANULMÁNYOK 6(2) pp. 6-24. 19 p.

KELEMEN, Z. (2006): Ökoturizmus. Természet - kultúra - harmónia. Magosfa Környezeti Nevelési és Ökoturisztikai Alapítvány, Vác

MICHALKÓ, G. (2011): Turisztikai terméktervezés és fejlesztés. http://www.eturizmus.pte.hu/szakmai-anyagok/Turisztikai terméktervezés és fejlesztés/book.html 
ORSZÁGOS ÖKOTURIZMUS FEJLESZTÉSI STRATÉGIA (2008): Pannon Egyetem Turizmus Tanszék - Aquaprofit Zrt., Veszprém-Budapest

RAFFAY, Z. (2009): A horgászturizmus eddigi eredményei és lehetőségei Magyarországon. In: Dávid, L. (szerk.): Fenntartható horgász-, vadász- és víziturizmus. Károly Róbert Főiskola, Gyöngyös, pp. 54-72.

RAFFAY,Z. (2014): Az ökoturizmus és a vallási turizmus lehetséges kapcsolódási pontjai. In: NFA Füzetek 3(1) pp. 52-60.

RAFFAY, Z. (2018): A horgászturizmus az ökoturisztikai kínálatban. In: Út” a XXI. században IX. Nemzetközi Turizmus Konferencia Tanulmányok. Széchenyi István Egyetem, Győr, pp. 157168.

RAFFAY, Z. (2020): A legnagyobb hazai civil szervezet, a Magyar Országos Horgász Szövetség mai és potenciális szerepe hazánk turizmusában. NFA Füzetek 6(1-2) pp. 23-35.

SZÉKELY, A. (2016): A horgászturizmus: lehetöségek és dilemmák. In: Jelenkori Társadalmi és Gazdasági Folyamatok XI. (1-2.). pp. 35-46.

THENG, S. - QIONG, X. - TATAR, C. (2015): Mass Tourism vs Alternative Tourism? Challenges and New Positionings. Études Caribbéennes. Letöltés helye és ideje: https://etudescaribeennes.revues.org/7708?lang=en , 2017. 07.28.

\section{Internetes források:}

DÉRER, I. (2021): Erkölcs, erő, egyetértés: a „szektor” jövőképe Magyarországon. Előadás a „A jövő kihívásai a horgászat és haltermelés területén” MOHOSZ - MA-HAL - MATE Hungexpo,

Budapest, 2021.10.03. https://nyito.mohosz.hu/index.php/szovetseg/9-hirek/823-a-jovo-kihivasai-a-horgaszat-eshaltermeles-teruleten, letöltés ideje: 2022. január 15.

FÜRÉSZ, GY. - ZELLEI, Á. (é.n.): A horgászat, a horgászturimus jövője és kapcsolata az akvakultúrával https://docplayer.hu/12517020-A-horgaszat-a-horgaszturimus-jovoje-eskapcsolata-az-akvakulturaval-furesz-gyorgy-es-zellei-agnes-magyar-orszagos-horgaszszovetseg.html, letöltés dátuma: 2022. január 15.

http://akvariumapartmanhazak.hu, letöltés dátuma: 2022. január 15.

http://www.mohosz.hu/images/pdfs/MOHOSZ_ALAPSZ_150529.pdf, letöltés dátuma: 2020. október 20.

https://balatonihal.hu/Cegunkrol/Bemutatkozas, letöltés dátuma: 2022. január 15.

https://ibcc.hu, letöltés dátuma: 2022. január 15.

https://nyito.mohosz.hu/index.php/versenysport/24-eredmenyek/805-a-sportszerusegalapkoevetelmeny-a-magyar-horgaszsportban-is-2, letöltés dátuma: 2022. január 15.

https://www.gianthuntersfishingholidays.com, letöltés dátuma: 2022. január 15.

https://www.wilddanube.ro

Nemzeti Élelmiszerlánc-biztonsági Hivatal (2018): Hazánkban a horgászat az egyik legnépszerübb szabadidős tevékenység - Jelentős mértékben növekszik a regisztrált horgászok létszáma. https://portal.nebih.gov.hu/hivatalunk/bemutatkozas/ismerje-meg-hivatalunkat, letöltés dátuma: 2022. január 15.

https://mtu.gov.hu/cikkek/aktiv-turizmus, letöltés dátuma: 2022. január 15. 
HALASI-KOVÁCSNÉ, B.B.R. - VASVÁRI, M. - MOLNÁRNÉ, B.R.K. (2014): A horgászturizmus gazdasági hatása a Tisza-tó térségében. https://geo.unideb.hu/hu/search/node/horgászturizmus

LUKÁCS, A. (2014): A balatoni horgászturizmus fejlesztése. https://docplayer.hu/26635780A-balatoni-horgaszturizmus-fejlesztese.html, letöltés dátuma: 2022. január 15. 